
A.A.Сайдуманев ${ }^{4}$

\title{
Клиническое значение лечебно-диетической коррекции белково-энергетической недостаточности у детей, подростков и взрослых, больных туберкулезом органов дыхания
}

1 - ГОУ ВПО "Московская медицинская академия им. И.М.Сеченова": 119991, Москва, ул. Трубецкая, 8, стр. 2;

2 - УРАМН "Центральный НИИ туберкулеза РАМН": 107564, Москва, ул. Яузская аллея, 2;

3 - ГУЗ "Областная клиническая туберкулезная больница": 150000, Ярославль, ул. Собинова, 43;

4 - ГУ "Республиканский противотуберкулезный диспансер МЗ ЧР": 364051, Чеченская Республика, Грозный, ул. Электротоковая, 3

\section{V.A.Aksenova, M.G.Biron, Z.Kh.Kornilova, V.V.Punga, K.A.Kordubaylo, N.I.Klevno, Yu.V.Makovey, A.A.Saydullaev Clinical value of dietary correction of protein and energetic deficiency in children, adolescents and adults with pulmonary tuberculosis}

\section{Summary}

This multi-center trial was designed to assess clinical value of dietary correction of protein and energetic deficiency in children, adolescents and adults with active pulmonary tuberculosis. The trial involved 460 patients treated for different clinical variants of pulmonary tuberculosis. The study group included 330 patients receiving nutritional supplements (dry protein composite DICO ${ }^{\circledR}$ "Nutrinor" and a specialized dry product for enteral nutrition "Nutrient Phtysio") added to a standard diet. The control group included 130 patients who received a standard diet and no nutritional supplements. Both the groups were also treated with standard anti-tuberculosis chemotherapy. Efficacy of dietary correction was assessed using scoring of tuberculosis intoxication syndrome, BMI, and routine clinical and radiological parameters. The vast majority of the study group patients (282 adults and 30 children and adolescents) demonstrated more rapid resolution of tuberculosis intoxication syndrome (in 4-5 weeks after starting the therapy). With a prompt regression of protein and energetic deficiency, this group had an accelerated growth in BMI, more rapid resolution of infiltrative and focal lung lesions, better tolerated chemotherapy with less frequent adverse events. Moreover, these patients more often became culturenegative and had cavities recovered. These results suggest that the dietary correction of protein and energetic deficiency in pulmonary tuberculosis patients using protein supplements is of great importance for real clinical practice independently on the patients' age.

Key words: protein and energetic deficiency, pulmonary tuberculosis, dry protein composite, dietary correction.

\section{Резюме}

С целью определения клинического значения лечебно-диетической коррекции белково-энергетической недостаточности у детей, подростков и взрослых, больных активным туберкулезом органов дыхания, проведено многоцентровое исследование 460 пациентов с различными клиническими формами специфического процесса в легких в фазе интенсивного лечения. Основную группу составили 330 больных, в рацион которых, основанный на традиционной диете, были включены сухая белковая композитная смесь ДИСО ${ }^{\circledR}$ Нутринор и продукт сухой специализированный для энтерального питания Нутриэн Фтизио. В контрольную группу исследования вошли 130 пациентов, у которых диета была традиционной, без применения данных лечебно-диетических белковых смесей. Больные обеих групп получали стандартную противотуберкулезную химиотерапию. Эффективность лечебной диеты оценивали с помощью анализа динамики выраженности синдрома туберкулезной интоксикации в баллах, изучения исходного дефицита массы тела, прибавки веса в процессе лечения, а также рутинных клинико-рентгенологических данных. Установлено, что у подавляющего большинства больных основной группы (282 взрослых, 30 детей и подростков) в процессе лечения регрессия синдрома туберкулезной интоксикации была более быстрой (в среднем через 4-5 нед. от начала лечения). На фоне выраженных темпов коррекции белково-энергетической недостаточности у больных этой группы наблюдалась ускоренная динамика восстановления массы тела, более значительное рассасывание инфильтративных и очаговых изменений в легких, улучшение переносимости лечения и снижение частоты побочных реакций на противотуберкулезные препараты. Кроме того, у пациентов, получавших лечебно-диетические белковые смеси в дополнение к традиционной диете, выявлена тенденция к более частому прекращению бактериовыделения и закрытию полостей распада. Полученные результаты свидетельствуют о большом практическом значении лечебно-диетической коррекции белково-энергетической недостаточности у больных активным туберкулезом органов дыхания различного возраста с помощью дополнительных белковых компонентов в рационе питания.

Ключевые слова: белково-энергетическая недостаточность, туберкулез органов дыхания, смесь белковая композитная сухая, лечебнодиетическая коррекция.

Нерациональное и несбалансированное питание, голодание, недостаточно качественный состав при туберкулезе способствуют прогрессированию специфического процесса, удлиняют срок лечения и ухудшают исход заболевания [1-5]. По данным
П.П.Сельцовского и В.И.Литвинова [6], неполноценное питание является существенным фактором риска развития туберкулеза. Частота этого фактора риска у впервые выявленных больных составляет 23-46 \%, что сопоставимо с такими важными факторами риска, 
как наличие установленного контакта с источником туберкулезной инфекции (37 \%) и психоэмоциональными перегрузками (42,2 \%) [6]. Недостаточное поступление пищи, потребление полноценных белков, полиненасыщенных жирных кислот, витаминов, минеральных веществ, микроэлементов, пищевых волокон и общая несбалансированность рациона усугубляются интоксикацией и нарушением аппетита, что приводит к развитию синдрома белково-энергетической недостаточности. Его выраженность, как правило, коррелирует с симптомами интоксикации и с потерей массы тела, что обычно происходит у больных активным туберкулезом на стационарном этапе в фазе интенсивного лечения [7].

Клинические наблюдения показывают, что при тяжелом течении туберкулезного заболевания синдром белково-энергетической недостаточности может быть исключительно резко выражен. Также анатомо-физиологические особенности детей и подростков нередко способствуют развитию его неблагоприятных проявлений, что может значительно ухудшать течение туберкулезной инфекции и состояние самих больных данного возраста. Эти известные в клинической практике пока недостаточно подробно отражены в исследованиях данной проблемы.

Установлено, что туберкулезная интоксикация повышает энергетические затраты больных различными клиническими формами туберкулеза на 15-20\%, достигая 3 100-3 500 ккал в сутки [7]. Неблагоприятная ситуация усугубляется тем, что традиционные лечебные диеты не обеспечивают сбалансированного поступления необходимых нутриентов. Кроме того, не все больные туберкулезом придерживаются рекомендованного режима питания. Это, в свою очередь, увеличивает белково-энергетическую разбалансированность у данной категории пациентов.

Согласно Приказам Минздравсоцразвития РФ № 316 от 26.04.06 и № 330 от 05.08.03 больным туберкулезом рекомендуется диета с повышенным содержанием белка, которая должна заменить диету № 11 по Певзнеру [8]. В Рекомендациях по организации питания больных туберкулезом подчеркивается целесообразность коррекции белковой составляющей рациона больных, получающих традиционные продукты, легкоусвояемым белком, обладающим высокой биологической ценностью [2]. В качестве дополнительного белкового компонента в рацион больных рекомендуется добавлять смеси белковые композитные сухие (СБКС) в количестве 20-50 \% от общего содержания белка в диете [2, 8]. В соответствии с Методическими рекомендациями Минздравсоцразвития № 2029-ВС от 16.12.05 в лечебном питании больных различными клиническими формами туберкулеза для повышения белковых и энергетических потребностей может также применяться продукт сухой специализированный для энтерального питания (ПССЭП) Нутриэн Фтизио [9]. Поскольку оба варианта коррекции лечебно-диетического рациона носят рекомендательный, а не обязательный характер, они осуществляются лишь в отдельных лечебно-профилактических противотуберкулезных учреждениях.
Опубликованные исследования клинического значения лечебно-диетической коррекции белковоэнергетической недостаточности у взрослых больных туберкулезом немногочисленны [1-5, 7, 10], а у больных туберкулезом детей и подростков - отсутствуют.

Цель настоящего исследования - установить клиническое значение лечебно-диетической коррекции белково-энергетической недостаточности у детей, подростков и взрослых, больных активным туберкулезом органов дыхания.

\section{Материалы и методы}

Исследованы клинические проявления синдрома белково-энергетической недостаточности, данные динамики выраженности синдрома туберкулезной интоксикации (в баллах), дефицит массы тела, результаты рутинных клинико-рентгенологических обследований 460 больных активным туберкулезом, которые в период интенсивной фазы противотуберкулезного лечения находились в противотуберкулезных стационарах различных лечебно-профилактических учреждений (многоцентровое исследование). 250 пациентов наблюдались в клинике ММА им. И.М.Сеченова, 160 - в Областной клинической туберкулезной больнице Ярославля, 50 - в Республиканском противотуберкулезном диспансере Чеченской Республики. В исследовании приняли участие 310 мужчин и 90 женщин в возрасте от 20 до 76 лет (80\% - 30-45 лет). Среди детей и подростков было 42 мальчика и 18 девочек. Распределение больных туберкулезом детей и подростков с нормальной массой тела и дефицитом на момент начала исследования (при поступлении в стационар) представлено на рис. 1, взрослых больных туберкулезом с нормальной массой тела и дефицитом - на рис. 2.

У 318 больных был инфильтративный туберкулез легких, у 71 - диссеминированный, у 28 - очаговый, у 24 - туберкулемы, у 10 - туберкулез внутригрудных

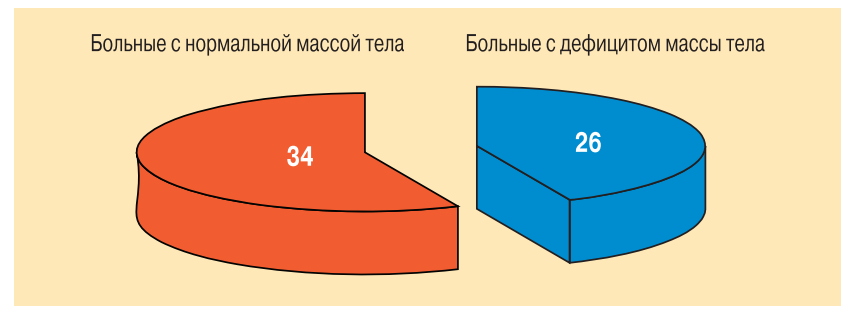

Рис. 1. Распределение больных туберкулезом детей и подростков с нормальной массой тела и ее дефицитом на момент начала исследования

Больные с нормальной массой тела

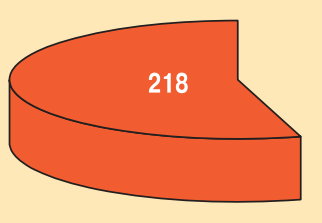

Больные с дефицитом массы тела

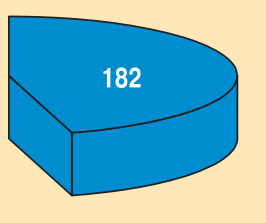

Рис. 2. Распределение взрослых больных туберкулезом с нормальной массой тела и ее дефицитом в период исследования 
Таблица 1

Пищевая и энергетическая ценность СБКС ДИСО ${ }^{\circledR}$ Нутринор в 100 г сухого продукта

\begin{tabular}{|lr|}
\hline Энергетическая ценность, ккал & 444,0 \\
\hline Белки, г & 40,0 \\
\hline Жиры, г & 20,0 \\
\hline Углеводы, г & 30,0 \\
\hline
\end{tabular}

Таблица 2

Пищевая и энергетическая ценность ПССЭП Нутриэн Фтизио в 100 г сухого продукта

\begin{tabular}{|lr|}
\hline Энергетическая ценность, ккал & 472,0 \\
\hline Белки, г & 22,0 \\
\hline Жиры, г & 20,0 \\
\hline Углеводы, г & 51,0 \\
\hline
\end{tabular}

лимфатических узлов, у 5 - плеврит, у 3 - кавернозный туберкулез, у 1 - казеозная пневмония. Основную группу составили 330 больных (300 взрослых, 30 детей и подростков). В рацион 150 взрослых и 15 детей и подростков этой группы к базисной диете была добавлена СБКС ДИСО ${ }^{\circledR}$ Нутринор (предоставлена Межрегиональным центром клинического питания, Россия). В рацион других 150 взрослых и 15 детей и подростков больных этой группы на основе базисной диеты был включен ПССЭП Нутриэн Фтизио (ЗАО "Нутритек", Россия).

Пищевая и энергетическая ценность СБКС ДИ$\mathrm{CO}{ }^{\circledR}$ Нутринор представлена в табл. 1.

СБКС ДИСО® Нутринор использовалась в качестве компонента приготовления готовых блюд в количестве, которое было регламентировано положениями Приказа Минздравсоцразвития РФ № 316 от 26.04.06, 2 раза в сутки (допускаемая кратность - от 1 до 3 раз в сутки) в составе крупяных, овощных блюд, соусов и фруктовых пюре.

Пищевая и энергетическая ценность ПССЭП Нутриэн Фтизио представлена в табл. 2.

ПССЭП Нутриэн Фтизио применялась в виде напитка или добавлялась в пищу в соответствии с методическими рекомендациями Минздравсоцразвития РФ [9].

В контрольную группу вошли 130 пациентов (100 взрослых, 30 детей и подростков), получавших стандартное противотуберкулезное лечение в соответствии с Приказом Минздравсоцразвития РФ № 109 от 21.03.03, а также базисную диету без СБКС и ПССЭП. Суточный рацион этих больных состоял из традиционных продуктов питания.

\section{Результаты и обсуждение}

Сопоставление динамики синдрома туберкулезной интоксикации у больных туберкулезом детей и подростков показывает, что у больных основной группы его симптомы регрессировали гораздо быстрее, чем в контрольной группе (рис. 3).

На фоне лечебно-диетической коррекции белково-энергетической недостаточности все клиничес-



Рис. 3. Динамика синдрома туберкулезной интоксикации у детей и подростков

кие проявления интоксикации разрешались к 5-й нед. интенсивной фазы противотуберкулезной химиотерапии у всех больных (30 человек) данного возраста. В то же время у 12 больных контрольной группы к 8-й нед. пребывания в стационаре еще сохранялись такие интоксикационные проявления, как анемия, диспепсия, слабость, вялость, эпизодические подъемы температуры. Дальнейшее наблюдение за этими детьми и подростками показало, что указанные симптомы интоксикации у них перестали определяться только через 4 мес. стандартной терапии (в фазе продолжения лечения). При сравнении темпов регрессирования интоксикационного синдрома в основной группе оказалось, что у больных туберкулезом детей и подростков они были более выраженными, чем у взрослых (рис. 4). Такая динамика может объясняться исходно менее тяжелым течением и распространенностью клинических форм туберкулеза у детей и подростков по сравнению с взрослыми больными. У подавляющего большинства взрослых больных туберкулезом основной группы (282 человек) выраженность симптомов интоксикации существенно уменьшались через 4-5 нед. от начала лечения, тогда как в контрольной группе это происходило заметно позже - после 8 нед. терапии (70 человек). Этот факт объясняется большей распространенностью специфического процесса и его

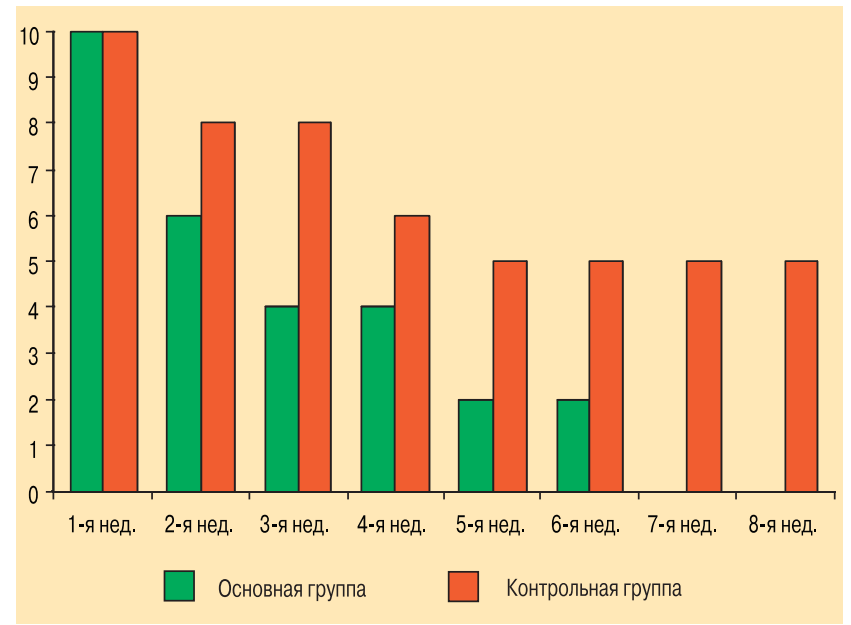

Рис. 4. Динамика синдрома туберкулезной интоксикации у взрослых больных 


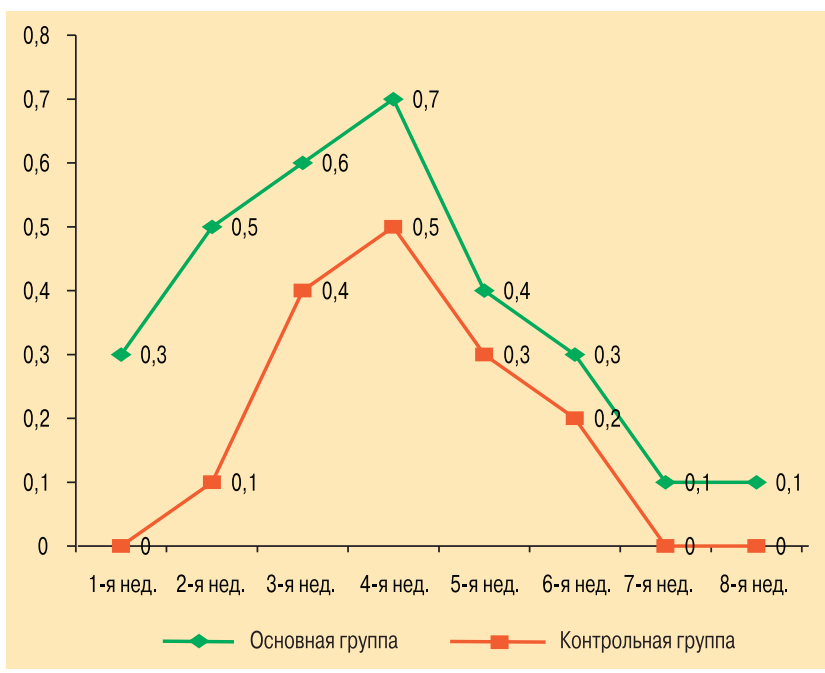

Рис. 5. Динамика нормализации массы тела в процессе лечебнодиетической коррекции белково-энергетической недостаточности и на фоне традиционного лечения у больных туберкулезом детей и подростков

тяжелым течением, наличием осложнений, сопутствующих заболеваний, нежелательных реакций на противотуберкулезные препараты, вредных привычек, факторов социальной дезадаптации у взрослых пациентов.

При изучении параметров дефицита массы тела у детей, подростков и взрослых также установлена лучшая положительная динамика восстановления веса на фоне диетотерапии с включением СБКС и ПССЭП в основной группе, по сравнению с контрольной. На фоне коррекции белкового компонента питания ежемесячная прибавка массы тела у больных основной группы превышала таковую в контрольной группе. Показатели еженедельной прибавки массы тела были максимальными в 1-й мес. интенсивной фазы противотуберкулезного лечения (рис. 5, 6).

Максимальное уменьшение дефицита массы тела наблюдалось у детей, подростков и взрослых, больных активным туберкулезом, к 4-5-й нед. терапии. Более медленной нормализация массы тела была среди больных с сохраняющимся синдромом туберкулезной интоксикации и совпадала с описанными выше отягощающими факторами течения туберкулезного процесса у взрослых больных. Этими же обстоятельствами объясняется относительно небольшая средняя прибавка массы тела у взрослых (ежемесячно - 2,2 кг) в сравнении с детьми и подростками (ежемесячно - 2,1 кг), как показано на рис. 5 и 6. Наряду с указанными клиническими результатами в основной группе (независимо от возраста пациентов) рассасывание инфильтративных и очаговых изменений в легких при рентгенологических контрольных исследованиях было более выраженным, чем в контрольной группе.

Установлена тенденция к более частому прекращению бактериовыделения и закрытию полостей распада в более короткие сроки у пациентов основной группы в сравнении с контрольной. Эти данные совпали с результатами ранее выполненных исследований среди впервые выявленных больных [7, 10].

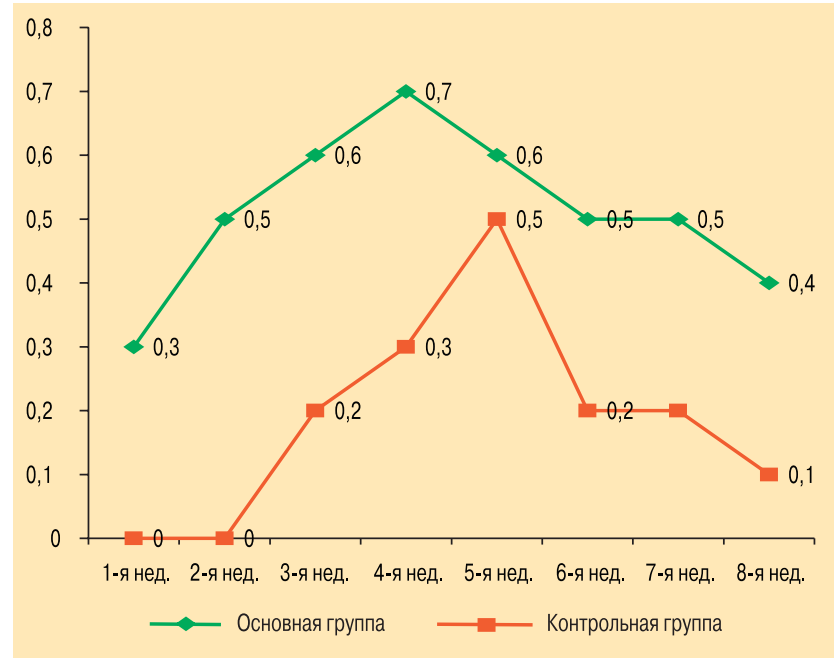

Рис. 6. Динамика нормализации массы тела в процессе лечебнодиетической коррекции белково-энергетической недостаточности и на фоне традиционного лечения у взрослых больных туберкулезом

Дальнейшее изучение проблемы, по-видимому, целесообразно проводить в группах больных активным туберкулезом органов дыхания с хроническим течением (кавернозным, фиброзно-кавернозным, хроническим гематогенно-диссеминированным, цирротическим), включая клинические формы процесса с лекарственной устойчивостью возбудителя.

Важным результатом исследования стал тот факт, что при использовании диетотерапии с включением СБКС ДИСО ${ }^{\circledR}$ Нутринор или ПССЭП Нутриэн Фтизио у больных любого возраста улучшилась переносимость лекарственных противотуберкулезных препаратов. При этом частота развития побочных реакций на химиотерапию у детей и подростков в основной группе оказалась в 3,5 раза ниже, чем в контрольной (5\% (2 человека) vs 17,5\% (5 человек)). У взрослых из основной группы частота развития побочных реакций была в 3 раза выше - у 5 \% (15 человек), чем в контрольной группе - у $15 \%$ (15 человек).

Установлена схожая клиническая эффективность лечебно-диетической коррекции белково-энергетической недостаточности при применении как СБКС ДИСО ${ }^{\circledR}$ Нутринор, так и ПССЭП Нутриэн Фтизио. Однако ПССЭП Нутриэн Фтизио оказался более удобным в использовании, т. к. позволял индивидуализировать рацион питания, варьируя суточную дозу в зависимости от выраженности белково-энергетической недостаточности и способ применения (в виде напитка или добавки к пище).

Полученные результаты свидетельствуют о большом практическом значении лечебно-диетической коррекции белково-энергетической недостаточности, позволяющей повысить эффективность и переносимость лечения.

\section{Заключение}

Нутритивная поддержка детей, подростков и взрослых больных туберкулезом органов дыхания путем применения в лечебно-диетическом питании дополнительных белковых компонентов имеет важное 


\section{ЭНTEPAАЬHОЕ ПИТАНИЕ}

Нутриэн

\section{фтизио}

Специализированная полноценная смесь с повышениыи содержанием белка и жора, обогащенная антиоксидантами и микроэлементами ( аскорбиновая кислота, цинк, карнитин, таурин) для лечебного питания больных различными формами туберкупеза с:

- белково-энергетической недостаточностыю при невозможности обеспечения адекватного поступления пищевых веществ

• поражениями желудочно кишечного тракта

- печеночной недостаточностыю

- тиреотоксикозом

. очаговыми поражениями легких
- послеоперационными осложнениями

- вторичной органной недостаточностью

- нервно-психической анорексией, тнжелой депрессией

- нарушениями иммунного статуса, а также

- во время предоперационной подготовки, в качестве послеоперачионного питания

Разработано совместно с НИИ питания РАМН.

Рекомендовано Российской ассоциацией парентерального и энтерального питания.

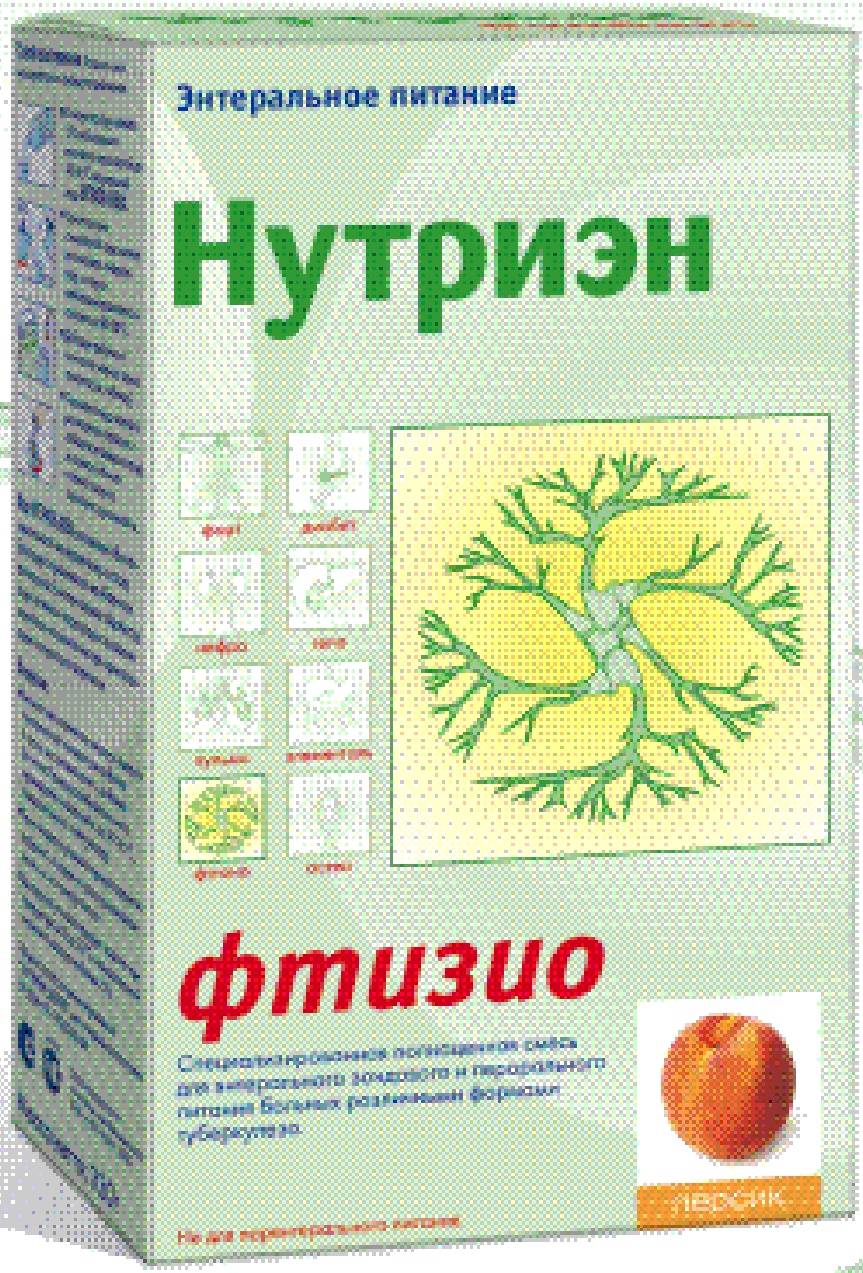

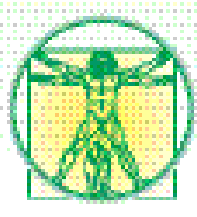

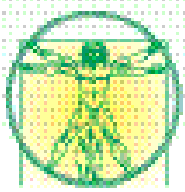

comandapm

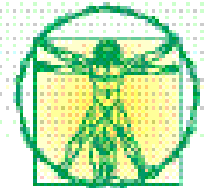

ascisy

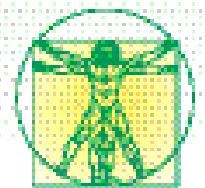

фераm

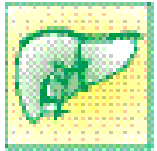

zena

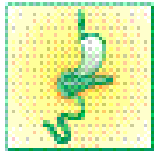

duebem

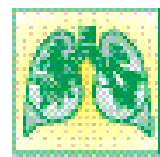

пуликse

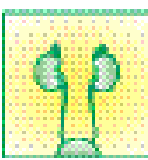

metpo

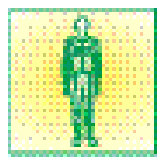

ecraeo



sanemenmam

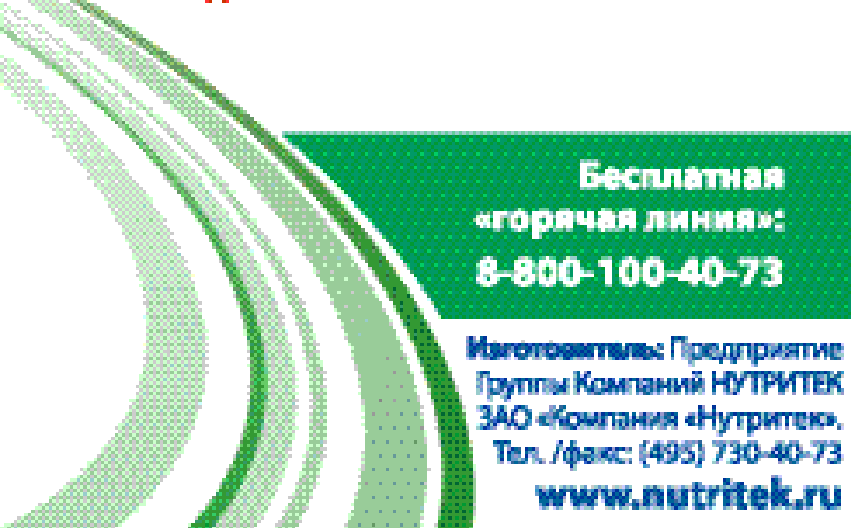


клиническое значение, позволяя ускорить темпы коррекции белково-энергетической недостаточности, ускорить динамику восстановления массы тела, улучшить переносимость лечения и снизить частоту побочных реакций на противотуберкулезные препараты. Своевременная коррекция белковой составляющей рациона больных с помощью СБКС ДИСО ${ }^{\circledR}$ Нутринор или ПССЭП Нутриэн Фтизио способствует скорейшему купированию синдрома туберкулезной интоксикации и улучшает репаративные процессы в легких (рассасывание очаговых и инфильтративных изменений). ПССЭП Нутриэн Фтизио более удобен для практического применения, поскольку позволяет индивидуализировать рацион питания пациентов. Рекомендуется более широкое использование лечебно-диетических смесей в лечебно-профилактических учреждениях фтизиопульмонологического профиля.

\section{Литература}

1. Данцев В.В. Клинико-гигиеническое обоснование совершенствования лечебного питания военнослужащих, больных туберкулезом: Автореф. дис. ... д-ра мед. наук. СПб.; 2009.

2. Рекомендации по организации питания больных туберкулезом: Инф. письмо. Минздравоохранениясоцразвития РФ. М.; 2009.

3. Van Lettow M., Harries A., Kumwenda J. et al. Micronutrient malnutrition and wasting in adults with pulmonary tuberculosis with and without HIV co-infection in Malawi. BMC Infect. Dis. 2004; 4: 61.

4. Schwenk A., Hodgson L., Wright A. et al. Nutrient partitioning during treatment of tuberculosis: gain in body fat mass but not in protein mass. Am. J. Clin. Nutr. 2004; 79 (6): 1006-1012.

5. Paton N., Chua Y.-K., Earnest A. et al. Randomized controlled trial of nutritional supplementation in patients with newly diagnosed tuberculosis and wasting. Am. J. Clin. Nutr. 2004; 80 (2): 460-465.
6. Сельцовский П.П., Литвинов В.И. Социальные аспекты эпидемиологической ситуации по туберкулезу. М.: Медицина и жизнь; 2004.

7. Бирон М.Г., Маковей Ю.В., Семенова Е.Е. и др. Лечебнодиетическая коррекция белково-энергетической недостаточности у больных туберкулезом органов дыхания смесью белковой композитной сухой в условиях противотуберкулезного стационара. Туб. и бол. легких 2010; 2: 40-43.

8. Приказ Минздравсоцразвития РФ № 316 от 26 апр. 2006 года "О внесении изменений в Приказ Министерства здравоохранения Российской Федерации от 5 августа 2003 года № 330 "О мерах по совершенствованию лечебного питания в лечебно-профилактических учреждениях Российской Федерации". М.; 2006.

9. Диетическая терапия больных туберкулезом: Метод. рекомендации Минздравсоцразвития РФ. М.; 2010.

10. Корнилова 3.Х., Алексеева Л.П., Атамановская К.М. и др. Эффективность использования продукта диетического питания - смеси белковой композитной сухой ДИСО "НУТРИНОР" в питании больных туберкулезом. Вестн. фтизиатр. 2008; 10: 48-51.

\section{Информация об авторах}

Аксенова Валентина Александровна - д. м. н., проф., зав. лабораторией по профилактике, диагностике и лечению туберкулеза у детей и подростков НИИ фтизиопульмонологии ММА им. И.М.Сеченова; тел.: (495) 631-11-12; e-mail: vaaksenova@mail.ru

Бирон Михаил Георгиевич - к. М. Н., доцент, старший научный сотрудник отдела эпидемиологии, статистики туберкулеза Центрального НИИ туберкулеза РАМН; тел.: (926) 084-51-81; e-mail: 681-75-66 @inbox.ru Корнилова Зульфира Хусаиновна - д. м. н., проф., руководитель отдела новых информационых технологий Центрального НИИ туберкулеза РАМН; тел.: (499) 785-91-87; e-mail: cniitramn@yandex.ru

Пунга Виктор Васильевич - д. М. Н., проф., руководитель отдела эпидемиологии, статистики туберкулеза Центрального НИИ туберкулеза РАМН; тел.: (499) 785-91-87; e-mail: cniitramn@yandex.ru

Кордубайло Константин Анатольевич - клинический ординатор кафедры фтизиопульмонологии ММА им. И.М.Сеченова; тел.: (495) 681-75-66; e-mail: korka24@yandex.ru

Клевно Надежда Ивановна - к. м. н., ведущий научный сотрудник лаборатории по профилактике, диагностике и лечению туберкулеза у детей и подростков НИИ фтизиопульмонологии ММА им. И.М.Сеченова; тел.: (495) 681-92-36; e-mail: niklevno@mail.ru

Маковей Юрий Васильевич - главный врач Областной клинической туберкулезной больницы; тел.: (485) 230-51-31; e-mail: tubdisp@mail.ru Сайдуллаев Арби-Хажи Абуезидович - главный врач Республиканского противотуберкулезного диспансера МЗ ЧР; тел.: (871) 222-34-90; e-mail: rptd@mail.ru 